\title{
Calbindin D-28k immunoreactivity in the rat accessory olfactory bulb
}

Authors:

A. Porteros, R. Arévalo, C. Crespo, E. García-Ojeda, J.G. Briñón, J. Aijón and J.R. Alonso

Running title:

CaBP-IR in the AOB

Institutional affiliation:

Departamento de Biología Celular y Patología

Universidad de Salamanca

E-37007 Salamanca

Spain

Correspondence to be sent to:

Dr. J. R. Alonso

Departamento de Biología Celular y Patología

Universidad de Salamanca

E-37007 Salamanca

Spain

Telephone number: +34-23-294400 ext. 1854

Fax number: +34-23-294549

E-mail: jralonso@gugu.usal.es 


\section{SUMMARY}

The distribution pattern and the morphology of calbindin D-28k-immunoreactive neurons were studied in the accessory olfactory bulb of the rat using a monoclonal antibody and the avidin-biotin-immunoperoxidase method. Positive neurons were observed in all layers but the vomeronasal nerve layer. Scarce monodendritic periglomerular neurons were calbindin D-28k immunoreactive. Different morphological types of short-axon cells were calbindin D-28k immunostained, with different degrees of intensity, in the boundary between the internal and external plexiform layer. In addition, deep short-axon cells located in the granule cell layer were calbindin D-28k-immunopositive. By contrast, previous studies described all cells in the rat accessory olfactory bulb as calbindin D-28kimmunonegative. The staining pattern in the rat accessory olfactory bulb showed both similarities and differences with the distribution pattern of the same calcium-binding protein in the main olfactory bulb.

\section{KEY WORDS}

Calcium-binding protein; Immunocytochemistry; Olfaction 


\section{INTRODUCTION}

Calcium ions are involved in a multitude of processes in the central nervous system, including axonal transport ${ }^{22}$, the exocytic release of neurotransmitters, and the movement of the axonal growth cone 27,28 . These calcium effects are mediated by a specific group of cytosolic proteins, the so-called calcium-binding proteins. Calbindin D-28k (CaBP) is a member of the EF-hand calcium-binding protein family which specifically binds intracellular free calcium in the micromolar range ${ }^{49}$. CaBP may either act as a calcium transporter or as an intracellular calcium buffer 8,29 , promoting or restricting calcium dependent events in the cellular metabolism. This protein might also serve to protect neurons in conditions of hypoxia or seizures, which can elevate intracellular calcium concentrations to toxic levels ${ }^{19,44}$. CaBP is a neuronal marker expressed in specific and widely distributed neuronal populations in the brain $3,4,5,10,11,18,36,42$. Immunocytochemical detection of CaBP reveals cells in a Golgi staining-like fashion.

All macrosmatic mammals have their chemoreception senses organized in three different systems: taste system, main olfactory system and vomeronasal or accessory olfactory system. The accessory olfactory system consists of receptor neurons located in the vomeronasal organ that send their axons to the accessory olfactory bulb (AOB) ${ }^{6}$, where these make synaptic contacts with the dendrites of mitral cells and tufted cells. The projecting neurons of the AOB connect with higher brain areas such as the bed nucleus of the accessory olfactory tract, the posteromedial cortical amygdaloid nucleus, the medial amygdaloid nucleus, the bed nucleus of the stria terminalis, and the supraoptic nucleus $14,38,39,45$. In rodents, the accessory olfactory system is thought to play a role in the pheromone chemoreception between conspecifics ${ }^{17,21}$, mechanism involved in reproductive and maternal behavior $7,13,25,30,48,50$. By contrast, the main olfactory system has a more generalized function, processing environmental chemical information with no predetermined meaning. 
In the main olfactory bulb (MOB) of the rat, cells of several classes of interneurons have been shown to be CaBP immunoreactive: periglomerular cells, superficial short-axon cells, external tufted cells, Van Gehuchten cells, horizontal cells, vertical cells of Cajal, and giant cells1,9,11,15,20,24,36,43. In previous studies on the localization of CaBP in the rat brain or in the olfactory bulb, the AOB was not included 1,9,15,20,24,43 or the absence of CaBP-immunoreactive cells was indicated ${ }^{11,36}$. By contrast, in a recent report on the distribution of NADPH-diaphorase and CaBP in the hedgehog olfactory bulb², CaBPimmunostained neurons were found in different layers of the AOB. In order to determine whether or not interspecies variations occur, the distribution of CaBP-immunoreactivity in the rat $\mathrm{AOB}$ is tested here. The aims of this study, therefore, are to describe in detail the morphological features of these positive elements and to compare our results with previous data on the distribution of this marker in the MOB and AOB of macrosmatic mammals.

\section{MATERIAL AND METHODS}

Five adult female Wistar rats weighing 250-300 g were used in this study. The animals were deeply anesthetized with ketamine (Ketolar, $50 \mathrm{mg} / \mathrm{kg}$ body weight), and after they were perfused transcardially with $100 \mathrm{ml}$ heparinized saline solution followed by 400 $\mathrm{ml}$ of a fixative containing $4 \%$ paraformaldehyde and 15\% saturated picric acid in $0.1 \mathrm{M}$ phosphate buffer (PB), $\mathrm{pH}$ 7.4. The brains were removed from the skull, postfixed in the same fixative for $6 \mathrm{~h}$ and immersed in PB containing 30\% sucrose (vol./vol.) for cryoprotection. Thereafter, the olfactory bulbs and olfactory peduncles were dissected out and frozen with liquid nitrogen. Coronal and sagittal sections (30 $\mu \mathrm{m}$ thickness) were cut with a cryostat (Bright) at $-21^{\circ} \mathrm{C}$, and processed free-floating for immunocytochemistry.

The sections were stained according to the avidin-biotin-immunoperoxidase method as described elsewhere ${ }^{2}$. The sections were sequentially incubated in: (a) $0.01 \%$ Triton X-100 in PB for $2 \mathrm{~h}$ at room temperature; (b) primary antibody (McAB 300 anti- 
calbindin D-28k) diluted 1:2000 in PB containing 10\% normal horse serum and $0.03 \%$ Triton X-100 for $48 \mathrm{~h}$ at $4^{\circ} \mathrm{C}$; (c) biotinylated anti-mouse immuno-gammaglobulin (Vector Labs., Burlingame, USA; 1:250 in PB; 3 h at room temperature; (d) Vectastain ABC reagent (Vector Labs.; 1:250 in PB; $90 \mathrm{~min}$ at room temperature); and (e) $0.07 \%$ 3, 3' diaminobenzidine (DAB) and 0.003\% hydrogen peroxide in $0.1 \mathrm{M}$ Tris-HCl buffer (pH 7.6). After each incubation step, the sections were rinsed in PB at room temperature. The reaction was monitored under the microscope. When the immunocytochemical procedure was concluded, sections were mounted on slides coated with gelatin chrome-alum, air-dried, dehydrated, cleared in xylene and coverslipped with Entellan. Cell sizes were measured using a Zeiss ocular micrometer.

The primary antibody against CaBP has been fully characterized ${ }^{12}$. Controls of the immunocytochemical procedure by omitting the first antibody or the second antibody in the incubation procedure, as described ${ }^{9}$ were also carried out. In both cases, no residual staining was observed in the AOB.

\section{RESULTS}

CaBP-immunostaining provided a Golgi-like labeling of cells and fibers in all layers of the AOB, except in the VNL. The highest number of CaBP-immunoreactive cells was found in the EPL/IPL boundary, whereas scarce immunopositive cells were also found in the GL, EPL and GCL. In addition, slightly CaBP-immunostained fibers were observed forming a plexus in the inner portion of the EPL. An schematic drawing of the distribution of CaBPpositive elements in the rat $\mathrm{AOB}$ is shown in Figure 1. In order to show clearly the similarities and differences with the MOB, a scheme of the CaBP-immunostaining pattern in the MOB is provided in the same figure.

Vomeronasal CaBP-positive fibers were not observed in our material, neither in the 
VNL nor in the GL. Scattered CaBP-labeled cells were demonstrated in the GL. These cells were spherical or ovoid, with a maximum diameter ranging from 8 to $10 \mu \mathrm{m}$ (Fig. 2a-c). According to their morphology and location, these neurons were identified as presumably periglomerular cells. Some periglomerular cells possessed a long dendrite that branched distant to the soma (Fig. 3c,d), whereas in other cells, the dendrite arborized close to the neuronal body (Fig. 3a,b). Only the initial portions of the axons of the periglomerular cells was immunostained (Fig. 3c). These axonal processes could be followed in the GL and in the superficial portion of the EPL. No other CaBP-immunopositive elements were observed in the GL.

Mitral cells and tufted cells, the output neurons of the rat AOB, were always CaBPimmunonegative. Small $(8-10 \mu \mathrm{m})$, and spherical cells in the EPL with a long prolongation directed towards the GL (Figs. 2d, 4a) were CaBP-immunostained. These neurons were identified as presumably displaced periglomerular cells.

The highest number of CaBP-immunostained neurons was observed in the IPL and at the EPL/IPL boundary (Fig. 2e,f,g). Both strongly and weakly CaBP-immunolabeled neurons were observed. The intensely stained neurons had round or piriform somata, between 10 and $15 \mu \mathrm{m}$ in maximum diameter. These immunopositive neurons were monopolar or bipolar, and their dendrites coursed parallel (Fig. 4c) or perpendicular (Fig. 4d) to the lateral olfactory tract. They resembled the horizontal neurons and the vertical cells of Cajal described in the MOB. The weakly labeled neurons were larger (17-20 $\mu \mathrm{m}$, maximum diameter), with oval or stellate cell bodies and two or three dendrites extending close to the neuronal body (Fig. 4b). A plexus of weakly CaBP-immunostained fibers, with unoriented trajectories, was observed at the EPL/IPL boundary, mainly located in the lateral regions of the AOB.

The largest CaBP-immunopositive neurons (20-25 $\mu \mathrm{m}$, maximum diameter) were observed in the innermost portion of the GCL. These neurons had fusiform cell bodies and 
relatively thin dendrites extending parallel to the GCL border (Fig. 2i,4f). Less frequently, the immunolabeled cells were stellate with two or three dendrites extending radially (Fig. 2h,4e). These cells were identified as deep short-axon cells. Occasionally, the same neuronal types were observed in the adjacent white matter that delimited the AOB from the anterior olfactory nucleus. No positive granule cells were observed.

\section{DISCUSSION}

We have found for the first time different types of CaBP-immunopositive neurons in the rat AOB, except in the VNL. By contrast, previous studies, either with polyclonal ${ }^{11,18}$ or monoclonal ${ }^{11,36}$ antibodies indicated the absence of CaBP-immunoreactive cells in the AOB. This controversy may be due to variations in the fixation or in the immunocytochemical treatment of the tissue. By contrast, whereas we have not observed positive labeling in the vomeronasal fibers of the rat, CaBP-immunoreactivity has been described in all these axons11,18,26. Nevertheless, those studies have used polyclonal antibodies, which may cross-react with calretinin, another calcium-binding protein highly homologous to CaBP ( $60 \%$ of coincidence in the primary aminoacid sequence) $)^{34,35,46}$. In this sense, strong calretinin-immunoreactivity has been observed in the VNL of the rat $\mathrm{AOB}^{23}$ and after labeling with a monoclonal antibody that does not cross-react with CaBP, vomeronasal fibers were CaBP-immunonegative ${ }^{36}$, as our observations demonstrated.

Numerous studies on the distribution of CaBP have been carried out in the MOB of the rat, and different types of immunopositive cells have been described. Both differences and similarities were detected with the CaBP-immunolabeling obtained in the AOB. Periglomerular cells were the only neuronal type referred as CaBP-immunoreactive by all authors describing the staining in the $\mathrm{MOB}^{1,4,9,11,15,18,20,24,41,43}$. In the $\mathrm{AOB}$, some periglomerular neurons were CaBP-positive, but they were much less abundant than in the MOB. Whereas about 12-13 CaBP-immunolabeled cells could be observed per sectioned 
olfactory glomerulus in each $30 \mu \mathrm{m}$ section ${ }^{1}$, only one or two CaBP-immunolabeled periglomerular cells, at most, were observed surrounding the rat vomeronasal glomeruli. Heterogeneous subpopulations of periglomerular neurons have been revealed in the rat MOB by immunocytochemical labeling against $\mathrm{CaBP}^{1,20,41}$, taurine ${ }^{37}$, tyrosine hydroxylase ${ }^{20,41}$, cholecystokinin $^{40}$, methionine-enkephalin ${ }^{31}$, somatostatin ${ }^{41}, \gamma$-aminobutyric acid 16,32 and NADPH-diaphorase ${ }^{1}$. In the AOB, subpopulations of periglomerular cells have been described as GABAergic ${ }^{47}$, NADPH-diaphorase positive ${ }^{33}$, and, in this report, as CaBPimmunoreactive, suggesting that a similar chemical heterogeneity of the periglomerular cells is present in the rat $\mathrm{AOB}$.

In the GL/EPL boundary of the rat MOB, CaBP-immunolabeled superficial shortaxon cells have been observed $1,9,41$. CaBP-immunolabeled cells with similar morphology (size, shape and location) were not observed in the AOB. By contrast, CaBP-immunolabeled deep short-axon cells of a similar size to those described in the AOB have not been observed in the rat MOB, whereas larger CaBP-immunoreactive cells, the so-called giant cells, were found in the white matter $9,11$.

In the EPL of the rat MOB, external tufted cells 11,20 and Van Gehuchten cells 1,9 have been referred as CaBP-immunopositive. The morphological characteristics of the labeled neurons of the AOB did not resemble any of these types. These cells possessed an intraglomerular dendrite, but we have not observed the presence of the "tuft", the typical feature of these cells. Concerning the large and weakly CaBP-immunoreactive cells described in the deep EPL of the AOB, their typification is uncertain since they did not resemble any of the neuronal types previously defined in the rat MOB or AOB.

In the IPL and at its border with the EPL, we observed intensely CaBPimmunostained cells. These neurons shared the size and branching pattern of the horizontal cells and vertical cells of Cajal described in the MOB as CaBP-immunoreactive ${ }^{9,11}$. Horizontal cells and deep short-axon cells have been described as NADPH-diaphorase 
positive interneurons in the rat $\mathrm{AOB}^{33}$. A double-labeling study is necessary to determine whether CaBP and NADPH-diaphorase are expressed by different neuronal subpopulations or are colocalized.

We have described the presence of CaBP-immunoreactive neurons and fibers in the $\mathrm{AOB}$ of the hedgehog ${ }^{2}$, an insectivore with an extraordinary development of olfactory structures. In this report, important interspecies differences were communicated in the CaBP-immunolabeling of the MOB between insectivores and rodents. By contrast, the same neuronal types that were CaBP-positive in the hedgehog AOB showed CaBPimmunoreactivity in the rat $\mathrm{AOB}$. Thus, the CaBP-immunostaining pattern in the $\mathrm{AOB}$ seems to be much more conserved than in the MOB between rodents and insectivores.

CaBP acts as a buffer of the intracellular concentration of calcium ions ${ }^{8,29}$, but the specific process controlled by this buffering mechanism remains unknown. In the rat brain, CaBP has been related to diffusely projecting unmyelinated systems in combination with different types of interneurons ${ }^{10}$. In the $\mathrm{MOB}, \mathrm{CaBP}$ was present in intrinsic interneurons, but it was not observed in the bulbar projecting neurons, in primary afferents or in centrifugal fibers ${ }^{9}$. These findings suggest a role for CaBP in the intrabulbar modulation of the olfactory signal. But the modulation possibilities are clearly lower in the AOB than in the $\mathrm{MOB}$, at least in the GL, since the number of CaBP-immunoreactive periglomerular neurons was reduced and CaBP-positive superficial short-axon cells were not observed.

\section{LIST OF ABBREVIATIONS}

AOB: Accessory olfactory bulb.

DCE: Deep cell of the external plexiform layer.

DPG: Displaced periglomerular cell.

DSA: Deep short-axon cell.

EPL: External plexiform layer. 
GIC: Giant cell.

GCL: Granule cell layer.

GL: Glomerular layer.

HZ: Horizontal cell.

IPL: Internal plexiform layer.

MCL: Mitral cell layer.

MOB: Main olfactory bulb.

PG: Periglomerular cell.

SSA: Superficial short-axon cell.

VC: Vertical cell of Cajal.

VG: Van Gehuchten cell.

VNL: Vomeronasal nerve layer

WM: White matter.

\section{ACKNOWLEDGEMENTS}

The authors would like to thank Prof. M.R. Celio for generously providing the monoclonal antibody used in this study. This work was supported by Junta de Castilla y León (JO-123) and DGICyT projects. 


\section{TABLE}

Table 1

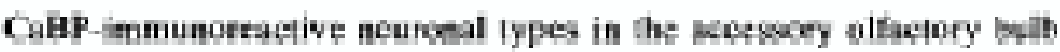

\begin{tabular}{|c|c|c|c|}
\hline Cell type & $\begin{array}{l}\text { Sire jain } \\
\text { (mean } \pm \text { S.E } M \text {. })\end{array}$ & Làiōn & Ficipusitisy \\
\hline Feriglomerular cell & $9.0 \overline{2} \pm 0.39$ & GL. & ++ \\
\hline Displased periglomerelur asll & $9.34 \pm 0.54$ & EPL & + \\
\hline Dexp acli of the FPl- & $18.8 . \pm 0.78$ & EPI. & +++ \\
\hline Harizonal celi & $11.86 \pm 0.33$ & IFL & ++ \\
\hline Verticil well of Cajal & $12.35 \pm 0.78$ & IPL & ++ \\
\hline Dexp̣ short-żơn celt & $22.60 \pm 0.86$ & GCL & + \\
\hline
\end{tabular}

Froquency: $+t+$, moet than $\$$ calls per section: $t+t, 1-5$ crlls per section; +, heos ban 1 cell per secrion. 


\section{REFERENCES}

1. Alonso, J.R., Arévalo, R., Porteros, A., Briñón, J.G., Lara, J. and Aijón, J., Calbindin D-28K and NADPH-diaphorase activity are localized in different populations of periglomerular cells in the rat olfactory bulb, J. Chem. Neuroanat., 6 (1993) 1-6.

2. Alonso, J.R., Arévalo, R., García-Ojeda, E., Porteros, A., Briñón, J.G. and Aijón, J., NADPH-diaphorase active and calbindin D-28k-immunoreactive neurons and fibers in the olfactory bulb of the hedgehog (Erinaceus europaeus), J. Comp. Neurol., 351 (1995) 307-327.

3. Andressen, C., Blümcke, I. and Celio, M.R., Calcium-binding proteins: selective markers of nerve cells, Cell Tissue Res., 271 (1993) 181-208.

4. Baimbridge, K.G., Miller, J.J. and Parkes, C.O., Calcium-binding protein distribution in the rat brain, Brain Res., 239 (1982) 519-525.

5. Baimbridge, K.G. and Miller, J.J., Immunohistochemical localization of calciumbinding protein in the cerebellum, hippocampal formation and olfactory bulb of the rat, Brain Res., 245 (1982) 223-229.

6. Barber, P.C. and Raisman, G., An autoradiographic investigation of the projections of the vomeronasal organ to the accessory olfactory bulb in the mouse, Brain Res., 81 (1974) 21-30.

7. Bean, N.J. and Wysocki, C.J., Vomeronasal organ removal and female mouse aggression: The role of experience, Physiol. Behav., 45 (1989) 875-882.

8. Braun, K., CaBPs in avian and mammalian central nervous system: localization, 
development and possible functions, Prog. Histochem. Cytochem., 21 (1990) 1-62.

9. Briñón, J.G., Alonso, J.R., Arévalo, R., García-Ojeda, E., Lara, J. and Aijón, J., Calbindin D-28k-positive neurons in the rat olfactory bulb, Cell Tissue Res., 269 (1992) 289-297.

10. Celio, M.R., Calcium binding proteins in the brain, Arch. Ital. Anat. Embriol., 94 (1989) 227-236.

11. Celio, M.R., Calbindin D-28k and parvalbumin in the rat nervous system, Neuroscience, 35 (1990) 375-475.

12. Celio, M.R., Baier, W., Schärer, L., Gregersen, H.J., de Viragh, P.A. and Norman, A.W., Monoclonal antibodies directed against the calcium binding protein calbindin D28k, Cell Calcium, 11 (1990) 599-602.

13. Clancy, A.N., Coquelin, A., Macrides, F., Gorski, A. and Noble, E.P., Sexual behavior and aggression in male mice: involvement of the vomeronasal system, J. Neurosci., 4 (1984) 2222-2229.

14. De Olmos, J., Hardy, H. and Heimer, L., The afferent connections of the main and the accessory olfactory bulb formations in the rat: an experimental HRP-study, J. Comp. Neurol., 181 (1978) 213-244.

15. Enderlin, S., Norman, A.W. and Celio, M.R., Ontogeny of the calcium-binding protein calbindin D-28k in the rat nervous system, Anat. Embryol., 177 (1987) 15-28.

16. Gall, C.M., Hendry, S.H.C., Seroogy, K.B., Jones, E.G. and Haycock, J.W., Evidence for coexistence of GABA and dopamine in neurons of the rat olfactory bulb, J. Comp. 
Neurol., 266 (1987) 307-318.

17. Gallego, A., Sánchez-Criado, J.E. and Mora, O., Role of the vomeronasal system in pheromonal reception in the rat. In J.E. Steimer and J.R. Ganchrow (Eds.), Determination of Behaviour by Chemical Stimuli, IRL Press, London, 1981, pp. 57-64.

18. García-Segura, L.M., Baetens, D., Roth, J., Norman, A.W. and Orci, L., Immunohistochemical mapping of calcium-binding protein in the rat central nervous system, Brain Res., 296 (1984) 75-86.

19. Goodman, J.H., Wasterlain, C.G., Massarweh, W.F., Dean, E., Sollas, A.L. and Sloviter, R.S., Calbindin D-28k immunoreactivity and selective vulnerability to ischemia in the dentate gyrus of the developing rat, Brain Res., 606 (1993) 309-314.

20. Halász, N., Hökfelt, T., Norman, A.W. and Goldstein, M., Tyrosine hydroxylase and 28k-vitamin D-dependent calcium binding protein are localized in different subpopulations of periglomerular cells of the rat olfactory bulb, Neurosci. Lett., 61 (1985) 103-107.

21. Halpern, M., The organization and function of the vomeronasal system, Ann. Rev. Neurosci., 10 (1987) 325-362.

22. Iqbal, Z. and Ochs, S., Fast axoplasmic transport of a calcium-binding protein in mammalian nerve, J. Neurochem., 31 (1987) 409-418.

23. Jacobowitz, D.M. and Winsky, L., Immunocytochemical localization of calretinin in the forebrain of the rat, J. Comp. Neurol., 304 (1991) 198-218.

24. Jande, S.S., Maler, L. and Lawson, D.E.M., Immunohistochemical mapping of vitamin 
D-dependent calcium-binding protein in brain, Nature, 294 (1981) 765-767.

25. Johns, M., The role of the vomeronasal organ in behavioral control of reproduction, Ann. N. Y. Acad. Sci., 474 (1986) 148-157.

26. Johnson, E.W., Eller, P.M., Jafek, B.W. and Norman, A.W., Calbindin-like immunoreactivity in two peripheral chemosensory tissues of the rat: taste buds and the vomeronasal organ, Brain Res., 572 (1992) 319-324.

27. Kater, S.B., Mattson, M.P., Cohan, C. and Connor, J., Calcium regulation of the neuronal growth cone, Trends Neurosci., 11 (1988) 315-321.

28. Kennedy, M.B., Regulation of neuronal function by calcium, Trends Neurosci., 12 (1989) 417-420.

29. Kretsinger, R.H., Mann, J.E. and Simmons, J.G., Model of facilitated diffusion of calcium by the intestinal binding protein. In A.W. Norman, K. Schaefer, D.V. Herrath and H.-G. Grigoleit (Eds.), Vitamin D: Chemical, Biochemical aand Clinical Endocrinology of Calcium Metabolism, De Gruyter, Berlin, 1982, pp. 233-248.

30. Lehman, M.N. and Winans, S.S., Vomeronasal and olfactory pathways to the amygdala controlling male hamster sexual behavior: autoradiographic and behavioral analyses, Brain Res., 240 (1982) 27-41.

31. Merchenthaler, I., Maderdrut, J.L., Altschuler, R.A. and Petrusz, P., Immunocytochemical localization of proenkephalin-derived peptides in the central nervous system of the rat, Neuroscience, 17 (1986) 325-348.

32. Mugnaini, E., Oertel, W.H. and Wouterlood, F.G., Immunocytochemical localization 
of GABA neurons and dopamine neurons in the rat main and accessory olfactory bulbs, Neurosci. Lett., 47 (1984) 221-226.

33. Porteros, A., Alonso, J.R., Arévalo, R., García-Ojeda, E., Crespo, C. and Aijón, J., Histochemical localization of NADPH-diaphorase in the rat accessory olfactory bulb, Chem. Senses, 19 (1994) 413-424.

34. Rogers, J.H., Calretinin: a gene for a novel calcium-binding protein expressed principally in neurons, J. Cell Biol., 105 (1987) 1343-1353.

35. Rogers, J.H., Khan, M. and Ellis, J., Calretinin and other calcium-binding proteins in the nervous system. In R. Pochet, D.E.M. Lawson and C.W. Heizmann (Eds.), Calcium-Binding Proteins in Normal and Transformed Cells. Adv. Exp. Med. Biol., Plenum Press, New York, 1990, pp. 195-203.

36. Rogers, J.H. and Résibois, A., Calretinin and calbindin D-28k in rat brain: patterns of partial co-localization, Neuroscience, 51 (1992) 843-865.

37. Sakai, M., Yoshida, M., Karasawa, N., Teramura-Ito, M., Nagatsu, T. and Nagatsu, I., Coexistence of taurine-like and tyrosine hydroxylase-like immunoreactivities in some periglomerular cells of the rat main olfactory bulb, Biogenic Amines, 4 (1987) 457-464.

38. Scalia, F. and Winans, S.S., The differential projections of the olfactory bulb and accessory olfactory bulb in mammals, J. Comp. Neurol., 161 (1975) 31-56.

39. Scalia, F. and Winans, S.S., New perspectives on the morphology of the olfactory system; olfactory and vomeronasal pathways in mammals. In R.L. Doty (Ed.), Mammalian Olfaction, Reproductive Processes, and Behavior, Academic Press, New York, 1976. 
40. Seroogy, K.B., Brecha, N. and Gall, C., Distribution of cholecystokinin-like immunoreactivity in the rat main olfactory bulb, J. Comp. Neurol., 239 (1985) 373383.

41. Seroogy, K.B., Hökfelt, T., Buchan, A., Brown, J.C., Terenius, L., Norman, A.W. and Goldstein, M., Somatostatin like immunoreactivity in rat main olfactory bulb: extent of coexistence with neuropeptide Y-, tyrosine hydroxylase- and vitamin D-dependent calcium binding protein-like immunoreactivities, Brain Res., 496 (1989) 389-396.

42. Séquier, J.M., Hunziker, W. and Richards, G., Localization of calbindin D-28k mRNA in rat tissues by in situ hybridization, Neurosci. Lett., 86 (1988) 155-160.

43. Séquier, J.M., Hunziker, W., Andressen, C. and Celio, M.R., Calbindin D-28k: protein and mRNA localization in the rat brain, Eur. J. Neurosci., 2 (1990) 1118-1126.

44. Sloviter, R.S., Calcium-binding protein (calbindin D-28k) and parvalbumin immunocytochemistry: localization in the rat hippocampus with specific reference to the selective vulnerability of hippocampal neurons to seizure activity, J. Comp. Neurol., 280 (1989) 183-196.

45. Smithson, K.G., Weiss, M.L. and Hatton, G.I., Supraoptic nucleus afferents from the accessory olfactory bulb: evidence from anterograde and retrograde tract tracing in the rat, Brain Res. Bull., 29 (1992) 209-220.

46. Strauss, K.I. and Jacobowitz, D.M., Nucleotide sequence of rat calretinin cDNA, Neurochem. Int., 22 (1993) 541-546.

47. Takami, S., Fernandez, G.W. and Graziadei, P.P.C., The morphology of GABA- 
immunoreactive neurons in the accessory olfactory bulb of rats, Brain Res., 588 (1992) 317-323.

48 Teicher, M.H., Shaywitz, B.A. and Lumia, A.R., Olfactory and vomeronasal system mediation of maternal recognition in the developing rat, Brain Res., 314 (1984) 97110.

49. Wassermann, R.H. and Taylor, A.N., Vitamin $\mathrm{D}_{3}$ induced calcium-binding protein in chick intestinal mucosa, Science, 152 (1966) 791-793.

50. Wysocki, C.J., Neurobehavioral evidence for the involvement of the vomeronasal system in mammalian reproduction, Neurosci. Biobehav. Rev., 3 (1979) 301-341. 


\section{FIGURE LEGENDS}

\section{Figure 1}

Schematic drawing showing the CaBP-immunostaining patterns in the rat $\mathrm{MOB}$ and $\mathrm{AOB}$. The AOB is a layered structure easily comparable to the MOB but less organized. Axons of the vomeronasal receptor cells arrive to the AOB where they form the VNL. These axons contact with dendrites of mitral cells, tufted cells, and periglomerular cells in the GL. In the AOB, mitral cells do not form a single row arrangement, but they are scattered in the EPL. The IPL is wide, and clearly distinguishable since it is occupied by the myelinated fibers of the lateral olfactory tract formed by the axons of output neurons located in the MOB and AOB. Numerous dendrites of granule cells located in the innermost stratum, the GCL, cross the IPL in dense bundles towards the EPL.

DCE: Deep cell of the external plexiform layer. DPG: Displaced periglomerular cell. DSA: Deep short-axon cell. GIC: Giant cell. HZ: Horizontal cell. MOB: Main olfactory bulb. PG: Periglomerular cell. SSA: Superficial short-axon cell. VC: Vertical cell of Cajal. VG: Van Gehuchten cell.

\section{Figure 2}

Camera lucida drawings of CaBP-immunopositive neuronal types in the rat AOB. Scale bar= $50 \mu \mathrm{m}$

a-c: Periglomerular cells

d: Displaced periglomerular cell

e: Deep cell of the EPL

f: Horizontal cell

g: Vertical cell of Cajal

h-i: Deep short-axon cells

EPL: External plexiform layer. GCL: Granule cell layer. GL: Glomerular layer. IPL: Internal plexiform layer. 


\section{Figure 3}

CaBP immunostaining in the GL of the AOB. Scale bar= $50 \mu \mathrm{m}$ (for all figures).

a.- Photographic composition showing two CaBP-immunopositive periglomerular cells.

b.- CaBP-immunoreactive periglomerular cell with two prolongations.

c.- CaBP-immunoreactive cell with a long dendrite. An axon-like prolongation can be observed (arrow).

d.- Inverted monopolar neuron with its neuronal body located at the VNL/GL boundary.

\section{Figure 4}

$\mathrm{CaBP}$ immunostaining in the deep layers of the rat $\mathrm{AOB}$. Scale bar= $50 \mu \mathrm{m}$ (for all figures).

a.- Displaced periglomerular cell located at the outermost region of the EPL.

b.- Round (solid arrow) and fusiform (open arrow) slightly CaBP-immunostained neurons located at the EPL/IPL boundary.

c.- A CaBP-immunopositive horizontal cell. Sagittal view of the IPL of the AOB.

d.- Vertical cell of Cajal in the IPL, with an apical dendrite directed towards the EPL.

e.- Multipolar CaBP-immunopositive deep short-axon cell located at the deepest portion of the GCL.

f- Bipolar fusiform CaBP-immunoreactive deep short-axon cell located at the boundary of the GCL with the anterior olfactory nucleus. 
CaBP-IR in the AOB

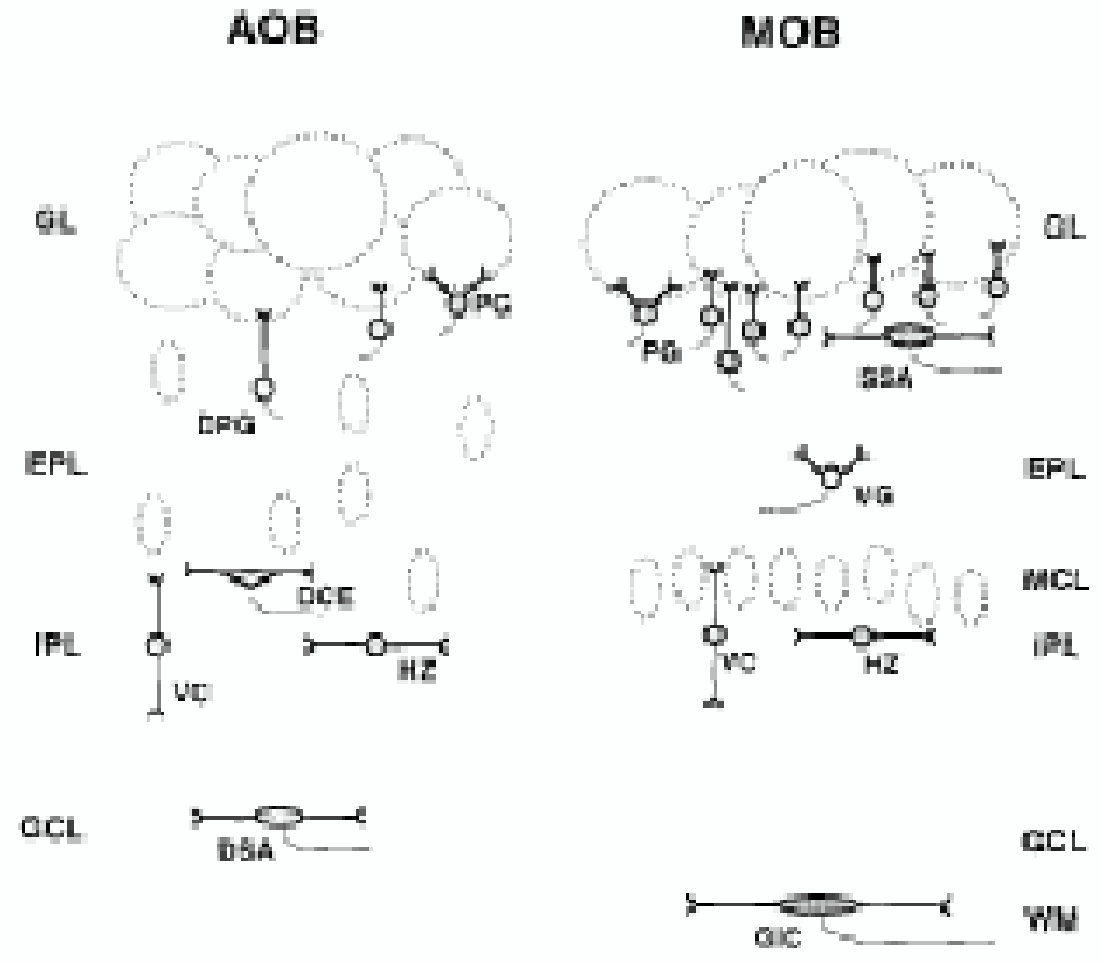




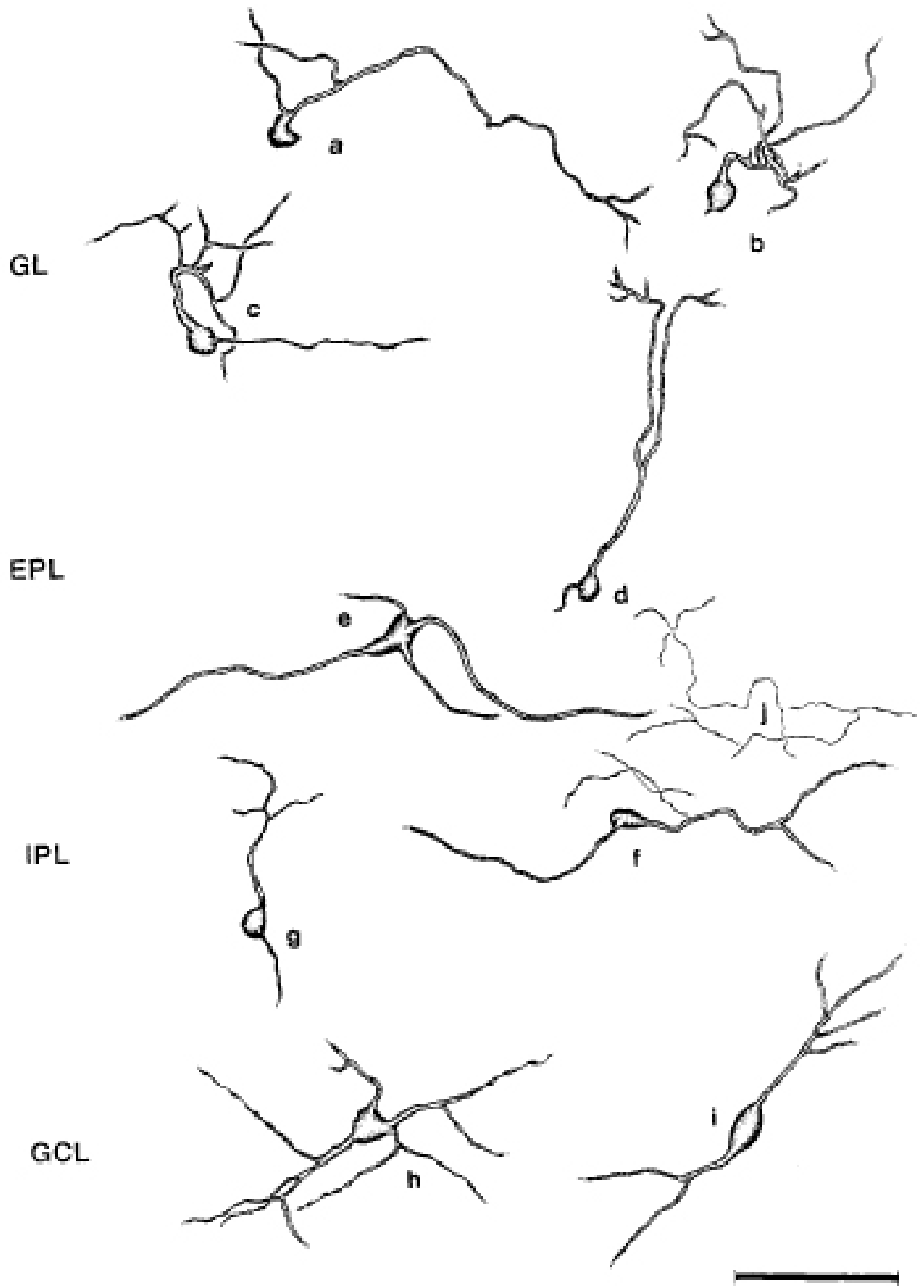




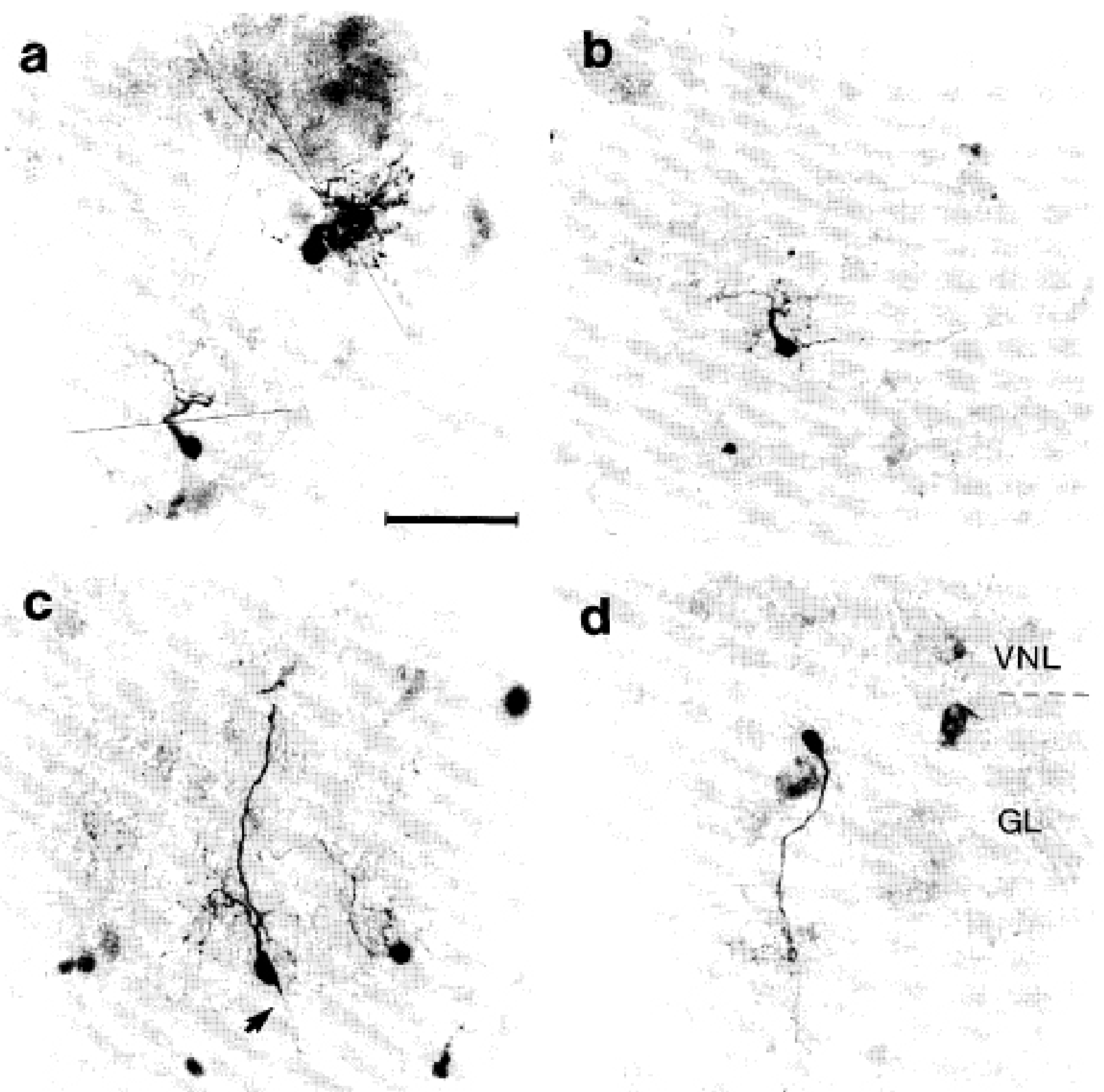



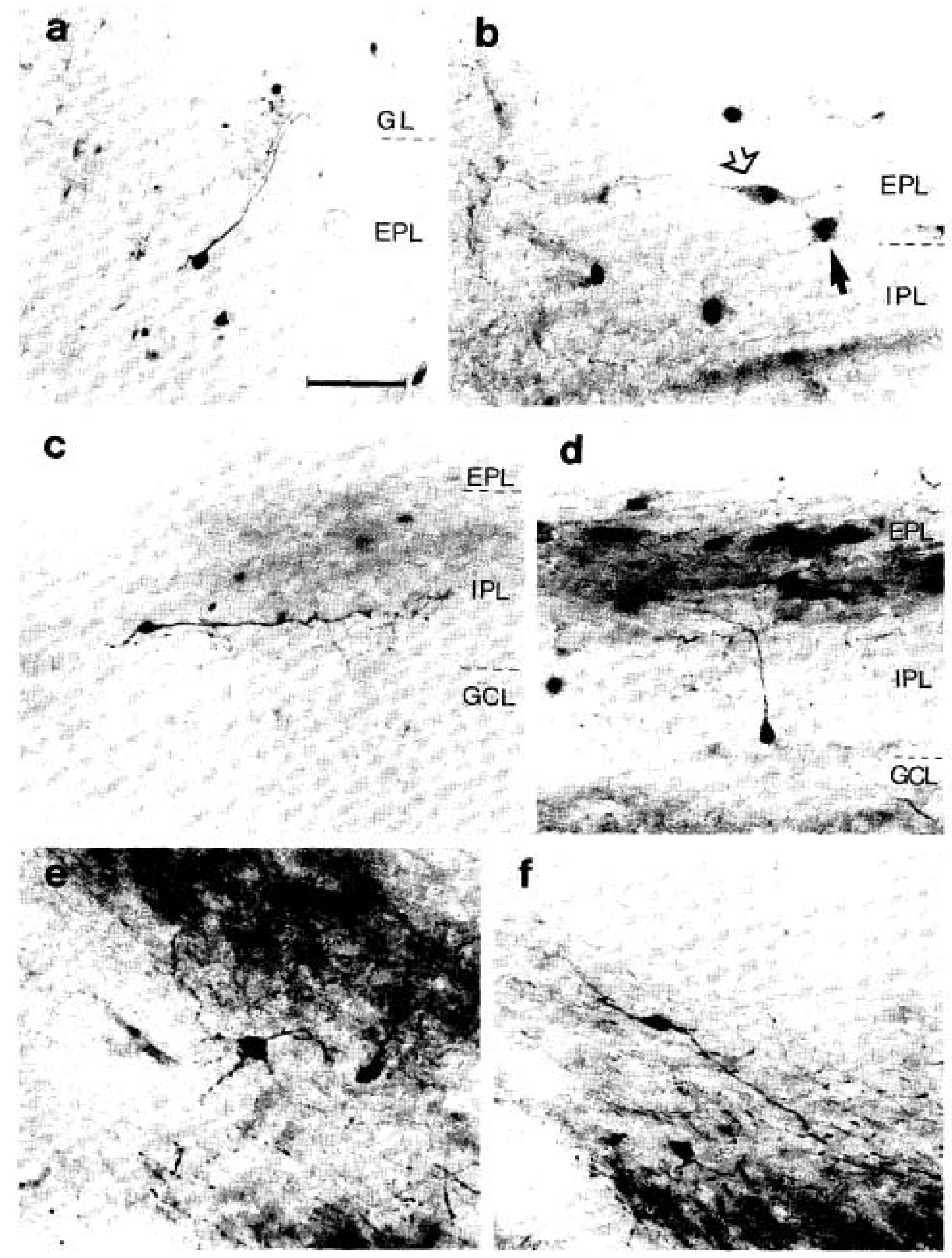